\title{
HUBUNGAN ANTARA SELF-REGULATED LEARNING DENGAN KEMAMPUAN PEMECAHAN MASALAH MATEMATIS \\ PADA MATA PELAJARAN MATEMATIKA KELAS VIII SMP NEGERI 3 CIPAKU TAHUN PELAJARAN 2011/2012
}

\author{
Lala Nailah Zamnah \\ Pendidikan Matematika, FKIP, Universitas Galuh Ciamis \\ e-mail: nailah_lala@yahoo.co.id
}

\begin{abstract}
ABSTRAK
Penelitian ini bertujuan untuk menelaah hubungan antara self-regulated learning siswa dan kemampuan pemecahan masalah matematis. Penelitian ini dilaksanakan di SMP Negeri 3 Cipaku dengan sampel peneltian kelas VIII-A dan VIII-C. Untuk mendapatkan data hasil penelitian digunakan instrumen berupa tes kemampuan pemecahan masalah matematis dan anket skala self-regulated learning. Analisis data menggunakan analisis korelasi dengan korelasi product moment. Hasil penelitian menunjukkan bahwa terdapat hubungan antara self-regulated learning siswa dengan kemampuan pemecahan matematis siswa.
\end{abstract}

Kata Kunci: self-regulateded learning, Kemampuan pemecahan masalah matemati 


\section{PENDAHULUAN}

Kemampuan pemecahan masalah sangat penting dimiliki setiap orang. Bukan hanya karena sebagian besar kehidupan manusia akan berhadapan dengan masalah-masalah yang perlu dicari penyelesaiannya, tetapi pemecahan masalah juga dapat meningkatkan daya analitis dan dapat membantu untuk menyelesaian permasalahan-permasalahan pada berbagai situasi yang lain. Hal ini sejalan dengan yang diungkapkan Cooney (Hudojo, 2003) bahwa dengan mengajarkan siswa untuk menyelesaikan masalah akan memungkinkan siswa tersebut menjadi lebih analitis mengambil keputusan dalam kehidupan.

Kemampuan pemecahan masalah tidak dapat berkembang dengan baik tanpa adanya kegiatan atau usaha untuk mengembangkan potensi-potensi kemampuan tersebut. Salah satu usaha yang dapat dilakukan untuk mengembangkan potensi-potensi kemampuan tersebut adalah melalui suatu program pendidikan. Salah satu program pendidikan yang dapat mengembangkan kemampuan pemecahan masalah adalah matematika. Hal ini sesuai dengan Depdiknas (2006) bahwa tujuan dari pelajaran matematika agar siswa memperoleh : (1) memiliki pengetahuan matematika (konsep, keterkaitan antarkonsep, dan algoritma); (2) menggunakan penalaran; (3) memecahkan masalah; (4) mengkomunikasikan gagasan dengan simbol, tabel,diagram, atau media lain untuk memperjelas keadaan atau masalah; dan (5) memiliki sikap menghargai kegunaan matematika. Menurut Branca (Sumarmo, 1994) kemampuan pemecahan masalah merupakan kemampuan yang harus dimiliki siswa, bahkan kemampuan pemecahan masalah matematis sebagai jantungnya dalam belajar matematika.

Selain kemampuan pemechan masalah yang harus dimiliki oleh siswa, terdapat juga soft skill yang harus dimiliki oleh siswa diantaranya adalah self-regulated learning.

Self-regulated learning adalah kemampuan siswa mengatur diri dalam belajar atau disebut juga kemandirian belajar siswa. Kemampuan mengatur diri dalam belajar matematika berperan dalam meningkatkan kualitas dan kuantitas diri dalam belajar. Secara prinsipil, self-regulated learning menempatkan pentingnya kemampuan seseorang untuk mengatur dan mengendalikan diri sendiri, terutama bila menghadapi tugas. Hal ini sesuai dengan yang diungkapkan Sumarmo (2004) bahwa kemandirian belajar merupakan proses perancangan dan pemantauan diri yang seksama terhadap proses kognitif dan afektif dalam menyelesaikan suatu tugas akademik. Apabila siswa mempunyai self-regulated learning yang tinggi cenderung belajar dengan lebih baik. Hal ini didukung oleh studi temuan Hargis (Sumarmo, 2004) bahwa individu yang memiliki self-regulated learning yang tinggi cenderung belajar lebih baik, mampu memantau, mengevaluasi, dan mengatur belajarnya secara efektif, menghemat waktu dalam menyelesaikan tugasnya, mengatur belajar dan waktu secara efisien, dan memperoleh skor yang tinggi dalam sains.

Rumusan masalah dalam penelitian ini adalah: Adakah hubungan antara selfregulated learning dan kemampuan pemecahan masalah matematis.

Tujuan dari penelitian ini adalah untuk menelaah hubungan antara self-regulated learning dan kemampuan pemecahan masalah matematis.

\section{SELF-REGULATED LEARNING}

Self-regulated merupakan perilaku seseorang yang mempunyai ciri mampu mengatasi hambatan dan masalah, mempunyai rasa percaya diri dan dapat melakukan sesuatu dengan sendiri tanpa bantuan orang lain. Sedangkan, self-regulated learning (kemandirian belajar) adalah kemampuan seseorang yang memiliki pengetahuan mengenai strategi belajar efektif dan mengetahui bagaimana serta kapan menggunakan pengetahuan tersebut sehingga siswa mampu mengatur diri dalam belajar.

Secara prinsipil, self-regulated learning menempatkan pentingnya kemampuan seseorang untuk mengatur dan mengendalikan diri sendiri, terutama bila menghadapi tugas. Hal ini sejalan dengan yang diungkapkan Zimmerman dan Martinez-Pons (1990) bahwa 
seorang siswa yang mempunyai kemandirian dalam belajar memperlihatkan kemampuannya dalam mengendalikan proses belajar sehingga berjalan dengan baik dan teryang memperoleh pembelajaran menggunakan pendekatan problem-centered learning tanpa hands-on activity, dan siswa yang mempunyai kemandirian dalam belajar memiliki tanggung jawab yang besar untuk berprestasi.

Menurut Sumarmo (2004) self-regulated learning atau kemandirian dalam belajar merupakan proses perancangan dan pemantauan diri yang seksama terhadap proses kognitif dan afektif dalam menyelesaikan suatu tugas akademik. Hargis (Sumarmo, 2004) menekankan bahwa selfregulated learning bukan merupakan kemampuan mental atau keterampilan akademik tertentu, tetapi merupakan proses pengarahan diri dalam mentransformasi kemampuan mental kedalam keterampilan akademik tertentu.

Schunk dan Zimmerman (1998) menggambarkan self-regulated learning sebagai proses belajar yang yang terjadi karena pengaruh dari pemikiran, perasaan, strategi, dan perilaku sendiri yang berorientasi pada pencapaian tujuan. Bandura (Sumarmo, 2004) mengidentifikasi karakter kemandirian belajar yaitu: mengamati dan mengawai diri sendiri, membandingkan posisi diri dengan standar tertentu, dan memberikan respon sendiri (respon positif atau negatif). Zimmerman (Pape, et al., 2003) mengungkapkan bahwa ada tiga tahapan dalam membangun kemandirian belajar, yaitu: 1) berfikir jauh kedepan. Siswa merencanakan kemandirian perilaku dengan cara menganalisis tugas dan menentukan tujuantujuan, 2) performasi dan kontrol. Siswa memonitor dan mengontrol dan mengontrol perilakunya sendiri, keasadaran, motivasi dan emosi, 3) Refleksi diri. Siswa menyatakan pendapat tentang kemajuan sendiri dan merubahnya sesuai dengan perilaku mereka.

Terdapat tiga tahap utama siklus selfregulated learning, yaitu merancang belajar, memantau kemajuan belajar selama menerapkan rancangan, dan mengevaluasi hasil belajar secara lengkap. Kegiatan masingmasing tahapan menurut Schunk dan Zimmerman dirinci sebagai berikut: 1) pada tahap merancang belajar berlangsung kegiatan: menganalisis tugas belajar, menetapkan tujuan belajar, dan merancang strategi belajar, 2) pada tahap memantau berlangsung kegiatan mengajukan pertanyaan pada diri sendiri: Apakah strategi yang dilaksanakan sesuai dengan rencana, Apakah saya kembali kepada kebiasaan lama, Apakah saya tetap memusatkan diri dan apakah strategi telah berjalan dengan baik. 3) pada tahap mengevaluasi dilakukan melalui pertanyaan: Apakah strategi telah dilaksanakan dengan baik (evaluasi proses); Hasil belajar apa yang telah dicapai (evaluasi produk); dan Sesuaikah strategi dengan jenis tugas belajar yang dihadapi.

Sejalan pendapat tersebut Rochester Institute of Technology (Sumarmo, 2004) mengidentifikasikan beberapa karakteristik kemandirian belajar, yaitu memilih tujuan belajar, memandang kesulitan sebagai tantangan, memilih dan menggunakan sumber yang tersedia, bekerjasama dengan individu lain, membangun makna, memahami pencapaian keberhasilan tidak cukup hanya dengan usaha dan kemampuan saja namun harus disertai kontrol diri.

Berdasarkan uraian yang telah dikemukakan, maka kemandirian belajar yang digunakan dalam penelitian ini adalah suatu disposisi matematis yang terdiri dari: (1) inisiatif belajar, (2) mendiagnosa kebutuhan belajar, (3) menetapkan tujuan belajar, (4) memonitor, mengatur dan mengontrol belajar, (5) memandang kesulitan sebagai tantangan, (6) memanfaatkan dan mencari sumber yang relevan, (7) memilih dan menetapkan strategi belajar yang tepat, (8) mengevaluasi proses dan hasil belajar, (9) konsep diri.

\section{PEMECAHAN MASALAH MATEMATIS}

Pemecahan masalah merupakan suatu proses untuk mengatasi kesulitan yang dihadapi untuk mencapai suatu tujuan yang ingin dicapai. Dalam pembelajaran matematika, pemecahan masalah adalah salah satu hasil yang ingin dicapai dan merupakan 
kemampuan yang diharapkan dapat diperoleh oleh siswa.

Pemecahan masalah adalah suatu proses untuk mengatasi kesulitan yang ditemui untuk mencapai suatu tujuan yang diinginkan (Sumarmo: 2000). Pemecahan masalah dalam matematika melibatkan metode dan cara penyelesaian yang tidak standar dan tidak diketahui sebelumnya (Turmudi, 2008).

Menurut Branca (Sumarmo, 1994) pemecahan masalah dapat diartikan dengan menggunakan interpretasi umum yaitu: pemecahan masalah sebagai tujuan, pemecahan masalah sebagai proses dan pemecahan masalah sebagai keterampilan dasar. Pemecahan masalah sebagai tujuan menyangkut alasan mengapa matematika itu diajarkan. Jadi dalam interprestasi ini pemecahan masalah bebas dari soal, prosedur, metode atau isi khusus, yang menjadi pertimbangan utama adalah bagaimana cara menyelesaikan masalah yang merupakan alasan mengapa matematika itu diajarkan.

Pemecahan masalah sebagai proses suatu kegiatan yang lebih mengutamakan pentingnya prosedur, langkah-langkah strategi yang ditempuh oleh siswa dalam menyelesaikan masalah, dan akhirnya dapat menemukan jawaban soal bukan hanya pada jawaban itu sendiri. Seperti yang diungkapkan oleh Ruseffendi (2006) bahwa pemecahan masalah adalah suatu pendekatan yang bersifat umum yang lebih mengutamakan kepada proses daripada hasilnya (output).

Jadi pemecahan masalah dalam matematika dipandang sebagai proses dimana siswa menemukan kombinasi prinsip-prinsip atau aturan-aturan matematika yang telah dipelajari sebelumnya dan digunakan untuk memecahkan masalah dengan memperhatikan langkah-langkah tertentu.

\section{LANGKAH-LANGKAH}

PEMECAHAN

\section{MASALAH MATEMATIS}

Dalam memecahkan masalah matematis, diperlukan langkah-langkah konkrit yang benar sehingga jawaban yang diperoleh pun dapat menjadi benar.

Ruseffendi (2006) mengemukakan bahwa dalam pemecahan masalah ada lima langkah yang harus dilakukan, yaitu: 1) menyajikan masalah dalam bentuk yang lebih jelas, 2) menyatakan masalah dalam bentuk yang operasional (dapat dipecahkan), 3) menyusun hipotesis-hipotesis alternatif dan prosedur kerja yang diperkirakan baik untuk dipergunakan dalam memecahkan masalah itu, 4) mengetes hipotesis dan melakukan kerja untuk memperoleh hasilnya (pengumpulan data, pengolahan data, dll); hasilnya mungkin lebih dari satu, 5) memeriksa kembali apakah hasil yang diperoleh itu benar; mungkin memilih pula pemecahan yang paling baik.

Sementara itu, Wahyudin (2008) menulis metode lima langkah pemecahan masalah Dewey: 1) Menyadari masalah, 2) Mendefinisikan (merumuskan) masalah tersebut, 3) Mengajukan berbagai hipotesis untuk memecahkannya, 4) Mengkaji konsekuensi-konsekuensi dari tiap hipotesis berdasarkan pengalaman yang telah lalu, dan 5) Menguji pemecahan yang paling mungkin.

Djamarah dan Zain (2006) menuliskan langkah-langkah pemecahan masalah berikut: 1) adanya masalah yang jelas untuk dipecahkan, yang tumbuh dari siswa sesuai dengan taraf kemampuannya, 2) mencari data atau keterangan yang dapat digunakan untuk memecahkan masalah tersebut, 3) menetapkan jawaban sementara dari masalah tersebut, 4) menguji kebenaran jawaban sementara tersebut, dan 5) menarik kesimpulan.

Menurut Polya (MKPBM, 2001) terdapat empat langkah dalam pemecahan masalah, yaitu : (1) memahami masalah, (2) merencanakan pemecahannya, menyelesaikan masalah sesuai rencana langkah kedua, (4) memeriksa kembali hasil yang diperoleh (looking back).

Polya (1973) mengemukakan proses yang dilakukan pada tiap langkah pemecahan masalah melalui pertanyaan: 1) pemahaman masalah (understanding the problem), diantaranya adalah: a) apakah yang tidak diketahui? b) data apa yang diberikan? c) apakah kondisi yang diberikan cukup untuk mencari apa yang ditanyakan?, 2) Membuat rencana pemecahan (devising a plan). Langkah ini menyangkut beberapa aspek 
diantaranya sebagai berikut: a) teori mana yang dapat digunakan dalam masalah ini?, b) perhatikan apa yang ditanyakan atau coba pikirkan soal yang pernah dikenal dengan pertanyaan yang sama atau yang serupa? c) dapatkah hasil dan metode yang lalu digunakan di sini?, d) apakah semua data dan kondisi sudah digunakan?, e) sudahkah diperhitungkan ide-ide penting yang ada dalam soal tersebut?, 3) melakukan perhitungan (carrying out the plan). Langkah ini menekankan pada pelaksanaan rencana penyelesaian. Prosedur yang ditempuh adalah: a) memeriksa setiap langkah apakah sudah benar atau belum?, b) bagaimana membuktikan bahwa langkah yang dipilih sudah benar?, 4) memeriksa kembali proses dan hasil (looking back) pada bagian akhir, Polya menekankan pada bagaimana cara memeriksa kebenaran jawaban yang telah diperoleh. Prosedur yang harus diperhatikan adalah : a) dapatkah diperiksa sanggahannya?, b) dapatkah jawaban tersebut dicari dengan cara lain?

\section{METODE PENELITIAN}

Penelitian ini bertujuan untuk menganalisis hubungan antara self-regulated learning dan kemampuan pemecahan masalah matematis siswa.

Penelitian ini dilaksanakan di SMP Negeri 3 Cipaku dan Subjek penelitian ini adalah seluruh siswa SMP Negeri 3 Cipaku tahun pelajaran 2011/2012. Sampel pada penelitian adalah kelas VIII-A dan VIII-C yang dipilih secara purposive.

Instrumen yang digunakan dalam penelitian ini adalah tes dan non-tes. Instrumen tes berupa soal-soal kemampuan pemecahan masalah matematis yang berupa soal uraian (essay), sedangkan instrumen nontes adalah angket skala self-regulated learning.

Teknik analisis data yang digunakan dalam penelitian ini adalah uji korelasi. Uji Korelasi antara self-regulated learning dengan kemampuan pemecahan masalah matematis siswa. Untuk melihat koefisien korelasi antara self-regulated learning dengan kemampuan pemecahan masalah maka kedua jenis data harus sama. Karena data kemampuan pemecahan masalah matematis merupakan data interval, sedangkan self-regulated learning merupakan data ordinal, maka data self-regulated learning harus ditransformasi terlebih dahulu menjadi data interval.

Setelah data self-regulated learning ditransformasi menjadi data interval, selanjutnya untuk melihat korelasi antara kemampuan pemecahan masalah matematis dan self-regulated learning siswa dengan menggunakan SPSS 16.0 for Windows.

\section{HASIL PENELITIAN DAN PEMBAHASAN}

Untuk melihat korelasi atau hubungan antara self-regulated learning dan kemampuan pemecahan masalah siswa dilakukan analisis korelasi. Hipotesis yang diajukan adalah terdapat hubungan antara selfregulated learning siswa dengan kemampuan pemecahan masalah matematis siswa.

Data yang digunakan untuk melihat korelasi antara self-regulated learning dan kemampuan pemecahan masalah matematis adalah data skor angket self-regulated learning dan data skor kemampuan pemecahan masalah matematis siswa. Data kemampuan pemecahan masalah matematis merupakan data interval, sedangkan selfregulated learning merupakan data ordinal, maka data self-regulated learning harus ditransformasi terlebih dahulu menjadi data interval. Setelah data self-regulated learning menjadi data interval, maka dilakukan uji korelasi. Data berdistribusi normal, sehingga uji korelasi menggunakan uji Korelasi Product Moment Pearson dengan taraf signifikansi $\alpha=0,05$. berikut:

Hipotesis yang diuji adalah sebagai

$\mathrm{H}_{0}$ :Tidak terdapat hubungan antara sel regulated learning siswa dan kemampuan pemecahan masalah matematis siswa

$\mathrm{H}_{1}$ :Terdapat hubungan antara self-regulated learning siswa dan kemampuan pemecahan masalah matematis siswa Tabel 1.
Hasil dari uji korelasi disajikan pada 
Dari tabel 1 terlihat bahwa hasil korelasi antara self-regulated learning dan kemampuan pemecahan masalah matematis siswa adalah 0,508 dan nilai signifikansi sebesar 0,000. Harga korelasi ( $r$ ) yang diperoleh adalah 0,508 yang artinya tingkat hubungannya tergolong tinggi. Nilai signifikansi sebesar 0,00 lebih

kecil dari $\alpha=0,05$, maka dapat disimpulkan bahwa hipotesis nol yang menyatakan tidak terdapat hubungan antara self-regulated learning siswa dengan kemampuan pemecahan masalah matematis siswa ditolak. Dengan demikian, terdapat hubungan antara self-regulated learning siswa dengan kemampuan pemecahan masalah matematis siswa.

Tabel 1

Uji Korelasi

\begin{tabular}{lcc}
\hline & SRL & $\begin{array}{c}\text { Pemecahan } \\
\text { Masalah } \\
\text { Matematis }\end{array}$ \\
\hline SRL $\begin{array}{l}\text { Pearson } \\
\text { Correlation }\end{array}$ & 1 & 0.508 \\
$\begin{array}{l}\text { Sig. (2- } \\
\text { tailed) }\end{array}$ & 0.000 \\
\hline $\mathrm{N}$ & 60 & 60 \\
\hline
\end{tabular}

\section{KESIMPULAN}

Berdasarkan penelitian dan pengolahan data, diperoleh kesimpulan bahwa Terdapat hubungan antara self-regulated learning siswa dengan kemampuan pemecahan masalah matematis siswa.

\section{DAFTAR RUJUKAN}

Depdiknas. (2006). Kurikulum 2006 Mata Pelajaran Matematika SMP/MTs. Jakarta: Dirjen Manajemen Dikdasmen Departemen Pendidikan Nasional.

Djamarah, S. B dan Zain, A. (2006). Strategi Belajar Mengajar. Jakarta: Rieneka Cipta.

Hudojo, H. 2003. Pengembangan Kurikulum dan Pembelajaran Matematika. Malang: Universitas Negeri Malang.
MKPBM Jurusan Pendidikan Matematika, Tim. (2001). Strategi Pembelajaran Matematika Kontemporer. Bandung : JICA UPI.

Pape, S.J, et. al. (2003). Developing in Mathematical Thinking and Self Regulated Learning: Teaching Elementary in Sevent-Grade Mathematics Classroom. Journal Educational Studies in Mathematics. 53, 179-202.

Polya, G. (1973). How to Solve It, a New Aspect of Mathematical Method. New Jersey: Princeton University Press.

Ruseffendi, E.T. (2006). Pengantar Kepada Membantu Guru Mengembangkan Kompetensinya Dalam Pengajaran Matematika Untuk Meningkatkan CBSA. Bandung:tarsito.

Schunk, D.H., dan Zimmerman, B. J. (1998). Self-Regulated Learning: From Teaching to Self-Reflective Practice. New York: Guilford Press.

Sumarmo, U. 1994. Suatu Alternatif Pengajaran untuk Meningkatkan Kemampuan Pemecahan Masalah pada Guru dan Siswa Sekolah Menengah Atas di Kodya Bandung. Laporan Penelitian IKIP Bandung. Tidak diterbitkan.

Sumarmo, U. (2004). Kemandirian Belajar, Apa, Mengapa dan Bagaimana Dikembangkan pada Peserta Didik. Laporan Penelitian UPI. Tidak diterbitkan.

Sumarmo, U. (2000). Pengembangan Model pembelajaran Matematika untuk Meningkatkan Kemampuan Intelektual Tingkat Tinggi Siswa Sekolah Dasar. Laporan Penelitian UPI. Tidak diterbitkan.

Turmudi. (2008). Landasan Filsafat dan Teori Pembelajaran Matematika (berparadigma Eksploratif dan Investigasi). Jakarta: Leuser Cita Pustaka. 
Wahyudin. (2008). Pembelajaran dan ModelModel Pembelajaran: Pelengkap untuk Meningkatkan Kompetensi Pedagogis Para Guru dan Calon Guru Profesional. Bandung: Diktat Perkuliahan UPI.

Zimmerman, B. J dan Martinez-Pons, M. (1990). Student Differences in Self Regulated Learning: Relating Grade, Sex, and Giftedness to Self-Efficacy and Strategy Use. Journal of Educational Psychology, 82(1).51-59. 
[.IICIIId Jurnal Teori dan Riset Matematika (TEOREMA) Vol. 1 No. 2, Hal, 38-38, Maret 2017 ISSN 2541-0660 @ 2017 